\title{
Temperature Distribution of Three-Dimensional Photovoltaic Panel by Using Finite Element Simulation
}

\author{
W.Z. Leow", Y.M. Irwan ${ }^{\#, *}$, M. Irwanto ${ }^{\#, 1}$, M Isa ${ }^{\#}$, A.R. Amelia ${ }^{\#}$, I. Safwati ${ }^{2}$ \\ ${ }^{*}$ Centre of Excellence for Renewable Energy, School of Electrical System Engineering, Universiti Malaysia Perlis, Malaysia. \\ E-mail:leowwaizhe@gmail.com \\ * Centre for Diploma Studies, Universiti Malaysia Perlis, Malaysia. \\ E-mail: irwanyusoff@unimap.edu.my \\ ${ }^{l}$ Department of Electrical Engineering, Medan Institute of Technology, Indonesia. \\ ${ }^{2}$ Institute of Engineering Mathematics, Universiti Malaysia Perlis, Malaysia.
}

\begin{abstract}
The low electricity performance of a photovoltaic (PV) panel has been concerned in the PV application system. The effect of environmental and operating condition was affected the performance of the PV panel. In this research work, the main objective is to perform a three-dimensional geometry model of monocrystalline silicon PV panel with and without cooling system by using finite element method. In the case of a cooling system, the effect of the Direct Current (DC) fan flow rate on the temperature distribution of PV panel was investigated. The electrical behaviour of this PV panel is obtained based on the average temperature of the PV panel obtained and average solar irradiance from site location. According to the experimental results, PV panel with cooling system can be significant to provide better performance than the PV panel without cooling system in the same environmental condition. For the effect of flow rate of DC fan in the PV panel with cooling system, the performance of this PV panel has been improved as increasing in flow rate of DC fan.
\end{abstract}

Keywords - PV panel, finite element method, cooling system, temperature distribution, output power

\section{INTRODUCTION}

Recently, renewable energy has been greatly adopted by many researchers. This is because to minimize the consumption of the conventional energy and reduce greenhouse effect. Among the renewable energy, PV energy is widely used than the others. The significant potential of PV energy is with a quickly raising part of PV in energy supply. It is clearly indicated that PV energy has a crucial position in the long-term energy supply. In the actual operation of the PV panel, only approximately $15 \%$ of the solar irradiance is converted into electrical energy, and the remainder is to heat energy [1].

This heat energy is affected by rising in operating temperature of the PV panel. This is led to the electrical efficiency of the PV panel will reduce. Previous research studies have stated that the electrical behaviour of PV panel reduced with increasing in its operating temperature. The electrical behaviour of the PV panel is dependent upon the parameters such as output voltage, output current, output power, fill factor and efficiency. According to the type of PV cell and encapsulation materials, various responses from PV cells increased the operating temperature beyond the specification [2]. Radziemska [3] reported that the output power drop of the PV panel was found to be $0.3 \% /{ }^{\circ} \mathrm{C}$ to $0.65 \% /{ }^{\circ} \mathrm{C}$ subjected to the type of the PV panel. Fahad AlAmri and Tapas Kumar Mallick [4] mentioned that when the PV panel exposed in a high level of solar irradiance, the operating temperature of the PV panel increased. This result leads to provide a negative coefficient to the electrical behaviour of the PV panel. A. D. Dhass et al. [5] pointed out that PV panel might perform better electrical efficiency at the lower operating temperature. Due to this fact, it is necessary to ensure that the operating temperature of PV panel is always maintained around the ideal level to resolve this issue.

With the intention to manage PV panel at lower operating temperature, researchers pay attention to cooling down the surface of PV panel. Thereafter, it can be dissipated heat away from the PV panel. Commonly, some techniques suggested decreasing the operating temperature of PV panel that includes air cooling, water cooling and heat sink cooling. 
However, many researchers suggested air cooling system to reduce the temperature of the PV panel. A. R. Amelia et al. [6] carried out a study of the different number of DC brushless fan required for the PV panel with air cooling system. It has been found out that the DC brushless fan is needed for a cooling system depends primarily on the total amount of heat energy required lost from the PV panel. The research work performed by O. Zogou and H. Stapountzis [7] focused on various operation modes of fan cooling system to enhance the performance of a building integrated photovoltaic (BIPV) to the Heating Ventilation and AirConditioning (HVAC) system of a building. It was analysed that increasing in fan capacity lead to the overall heat transfer and PV panel cooling effect increased as well.

F. Sarhaddi et al. [8] conducted an experimental simulation analysis on the performance of photovoltaic/thermal (PV/T) air collector. The operating temperature of the $\mathrm{PV} / \mathrm{T}$ air collector was increased along with the rise in solar irradiance intensity. This is led to the electrical efficiency of the collector decline. Similarly, JinHee Kim et al. [9] were integrated air-based system with the $\mathrm{PV} / \mathrm{T}$ air collector in order to reduce operating temperature of PV panel. In this study, the fan was used to exhaust heat away from the PV panel. According to this investigation, the average electrical efficiency of PV/T air collector can be collected at $15 \%$. An experimental study was carried by Y.M. Irwan et al. [10] to analyse the effect of the air cooling system on the performance of the PV panel. This investigation was conducted by using a solar simulator in the indoor testing. This PV panel with the air cooling system can be decreased $2-3{ }^{\circ} \mathrm{C}$ along with increment in $6-14 \%$ of output power depend on various fixed of solar irradiance intensity.

In a research work by A. S. Kaiser et al. [11] was applied a forced air convection cooling system in the rear side of PV panel integrated with rooftop. This cooling system used fan provided airflow passes air channel to reduce the operating temperature of the PV panel. This was lead to generated better performance of PV panel. Niccole Aste et al. [12] were constructed and analysed PV/T system integrated with building. This system was combined with air collector to dissipate the heat energy in order to reduce the operating temperature of PV panel. The reason for this was increased the electricity performance of the PV panel.

The objective of this present paper is to investigate the thermal behaviour and electrical behaviour of a PV panel integrated with a DC fan cooling system. ANSYS CFX was employed to develop a three-dimensional simulation model in this investigation. The performances of the PV panel with and without DC fan cooling system have been compared in this paper. In addition, the effect of the flow rate from the DC fan on the thermal and electrical performance of a PV panel has been studied detail in next section.

\section{THE MATERIAL AND METHOD}

ANSYS CFX simulation software was utilized to analyse the thermal model of PV panel. This software was used to develop a three-dimensional geometry model that simulates the temperature distribution in monocrystalline silicon PV panel. In the specifications of manufacturer, the maximum peak power of this PV panel is $100 \mathrm{Watts}$ under standard test condition (STC). As well to know that, the temperature distribution which varied according to the PV panel materials, type of PV cell, the PV panel construction, the existing environmental condition and, in the scenario of a cooling system, the capabilities of the heat exchanger as well.

The dimensional of this PV panel model has a size of $120 \mathrm{~cm} \times 54 \mathrm{~cm} \times 3 \mathrm{~cm}$ (Length $\times$ Width $\times$ Height $).$ It comprised of six layers: glass covering, Ethylene Vinyl Acetate (EVA) layer 1, monocrystalline silicon PV cells, EVA layer 2, Tedlar and aluminium frame from top to bottom, respectively. In the case of DC fan cooling system, it consists of additional two layers that are air channel and aluminium metal sheet. Which, the DC fans attached to the aluminium metal sheet, and it was assembled at the backside of the aluminium frame. This construction was created a channel through which air flows. The geometry of this simulation model is displayed in Fig 1. The parameters of each layer are listed out in Table 1.

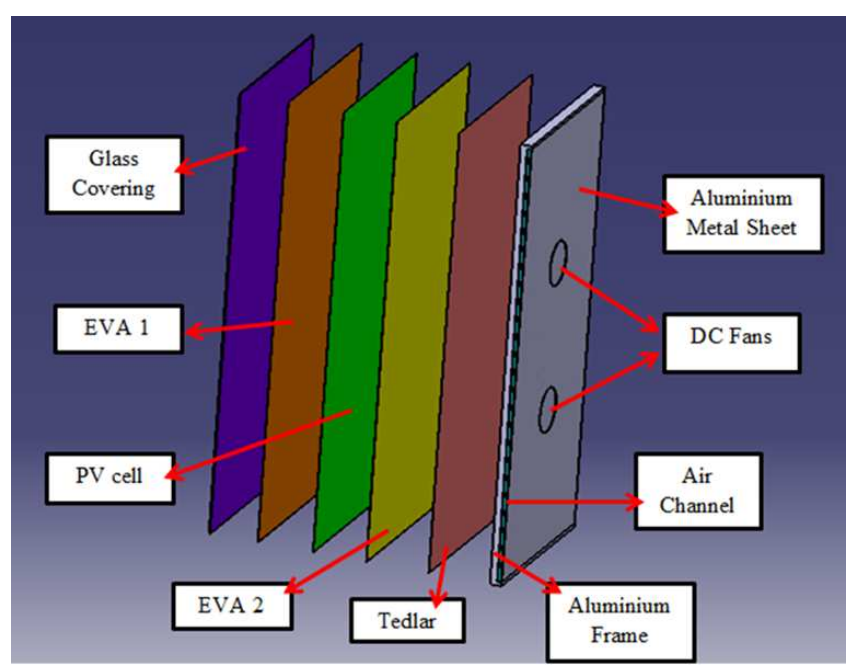

Fig. 1 Sketch of the PV panel geometry model

TABLE I

MATERIAL PROPERTIES AND SIZES OF EACH LAYER IN PV PANEL

\begin{tabular}{|c|l|c|c|c|c|}
\hline No. & $\begin{array}{c}\text { Material } \\
(\text { Layer })\end{array}$ & $\begin{array}{c}\text { Thick } \\
(\mathbf{c m})\end{array}$ & $\begin{array}{c}\text { Thermal } \\
\text { Conductivity } \\
\left(\mathbf{W} / \mathbf{m}^{\circ} \mathbf{C}\right)\end{array}$ & $\begin{array}{c}\text { Specific } \\
\mathbf{H e a t} \\
\mathbf{C a p a c i t y} \\
\left(\mathbf{J}^{\circ} \mathbf{k g}{ }^{\circ}\right)\end{array}$ & $\begin{array}{c}\text { Density } \\
\left(\mathbf{k g} / \mathbf{m}^{\mathbf{3}}\right)\end{array}$ \\
\hline 1. & $\begin{array}{l}\text { Glass } \\
\text { Covering }\end{array}$ & 0.3 & 1.8 & 500 & 3000 \\
\hline 2. & $\begin{array}{l}\text { EVA layer } \\
\text { 1\& 2 }\end{array}$ & 0.05 & 0.35 & 2090 & 960 \\
\hline 3. & PV Cell & 0.04 & 148 & 677 & 2330 \\
\hline 4. & Tedlar & 0.01 & 0.2 & 1250 & 1200 \\
\hline 5. & $\begin{array}{l}\text { Aluminum } \\
\text { Frame }\end{array}$ & 2 & 204 & 996 & 2707 \\
\hline 6. & $\begin{array}{l}\text { Aluminum } \\
\text { Sheet }\end{array}$ & 0.05 & 204 & 996 & 2707 \\
\hline
\end{tabular}

In the procedure to simulate the geometry model, the first step is to use CATIA V5 software was modelled the geometry design. The next process is meshing that to break the geometry model into elements. This was implemented in ANSYS Mechanical. After that, this ANSYS Mechanical was to add the boundary conditions to the geometry model and defined the material properties of each layer as well. The 
solar irradiance was applied to the outer layer of glass covering. In the case of PV panel without cooling system, the natural convection heat transfer was added to the outer layer of the geometry model, which is glass covering and tedlar. Whereas, in the case of PV panel with cooling system, the natural convection heat transfer was added to the outer layer of the glass covering. The forced convection heat transfer was applied in the air channel. This geometry model was employed to measure and analyse the transient thermal response of the PV panel with and without the DC fan cooling system. This transient thermal response for both geometry models was carried out in 3600 seconds.

In the simulation of PV panel with the cooling system, the operating parameter of the cooling system also influenced the performance of the PV panel. In this research, the effect of the flow rate from the DC fan was studied. This is due to the flow rate of the DC fan is an important operating factor that determined the effect of cooling on the performance of the PV panel. The selected range of DC fan flow rate was taken from $2 \mathrm{~m} / \mathrm{s}$ to $10 \mathrm{~m} / \mathrm{s}$.

The external inputs for this simulation required are the environmental and operating condition data. The data of environmental condition is obtained from the site location (Perlis, Malaysia) by using DAVIS Vantage Pro2 Weather Station. That is, the average solar irradiance intensity of $589.3 \mathrm{~W} / \mathrm{m}^{2}$, average ambient temperature of $32.97{ }^{\circ} \mathrm{C}$ and average wind speed of $4.91 \mathrm{~m} / \mathrm{s}$ throughout the year 2015 is applied to the simulation. Aside from that, in the case of DC fan cooling system, two units of DC fans were constantly provided the cool air to the PV panel under different flow rate of DC fan. While the heat energy was dissipated from side of the PV panel as illustrated in Fig. 2.

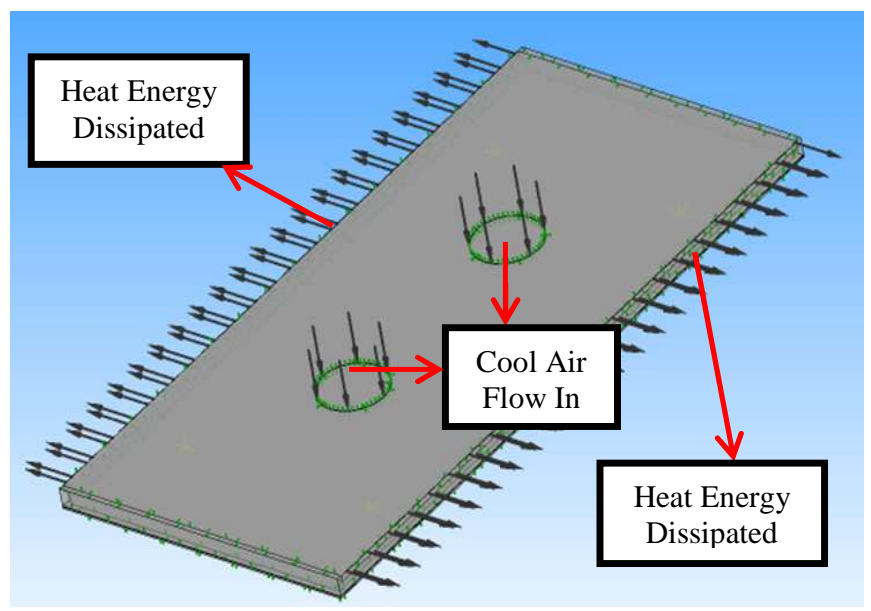

Fig. 2 Air flow circulation for the DC fan cooling system

"Probe" tool used to act as a thermocouple that attached to the backside of the geometry model. Four units of thermocouples used to detect the temperature of the PV panel as shown in Fig. 3. The average temperature distribution obtained from the thermal model is input in the electrical model to calculate the output power generated by the PV panels. In the prediction of the electrical energy, PVsyst software was used to simulate this electrical model.

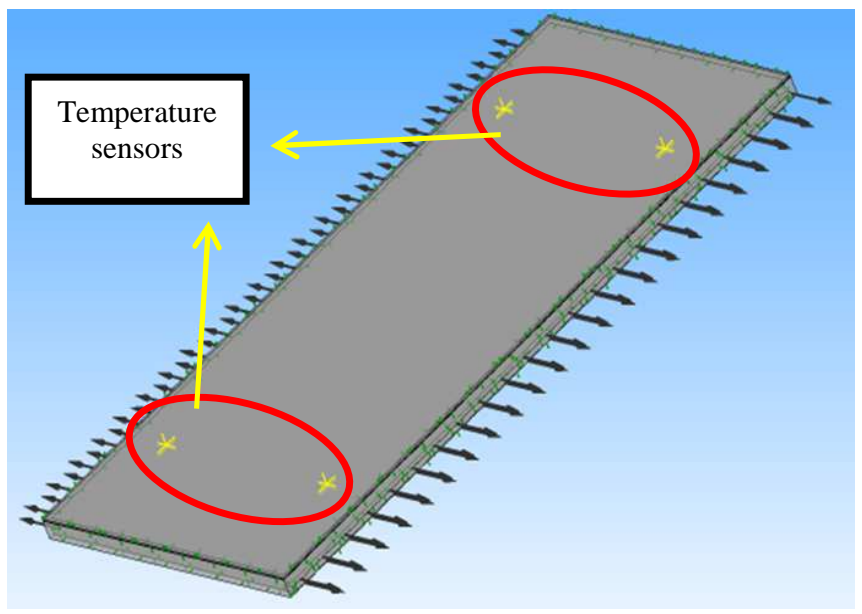

Fig. 3 Temperature sensors attached at backside of geometry model

\section{RESULTS AND DISCUSSION}

The results obtained from the simulation analysis of the PV panel with and without DC fan cooling system are described in this section. In addition, it is possible to observe the relationship between the effect of the DC fan flow rate and temperature distribution of the PV panel based on the simulation results. The average solar irradiance, average ambient temperature and average wind speed for the PV panel site location have been used in the thermal model for calculating the temperature distribution of the PV panel.

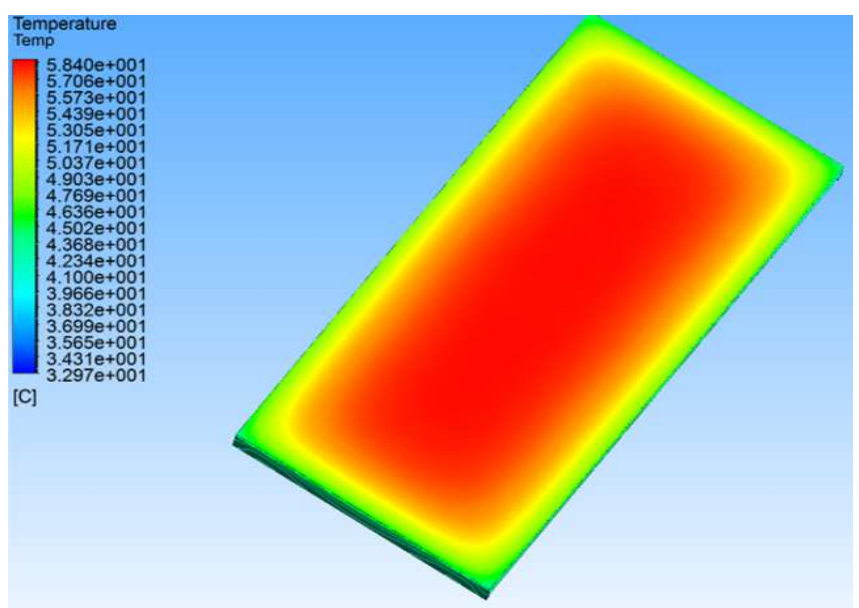

Fig. 4 Temperature distribution of PV panel without cooling system

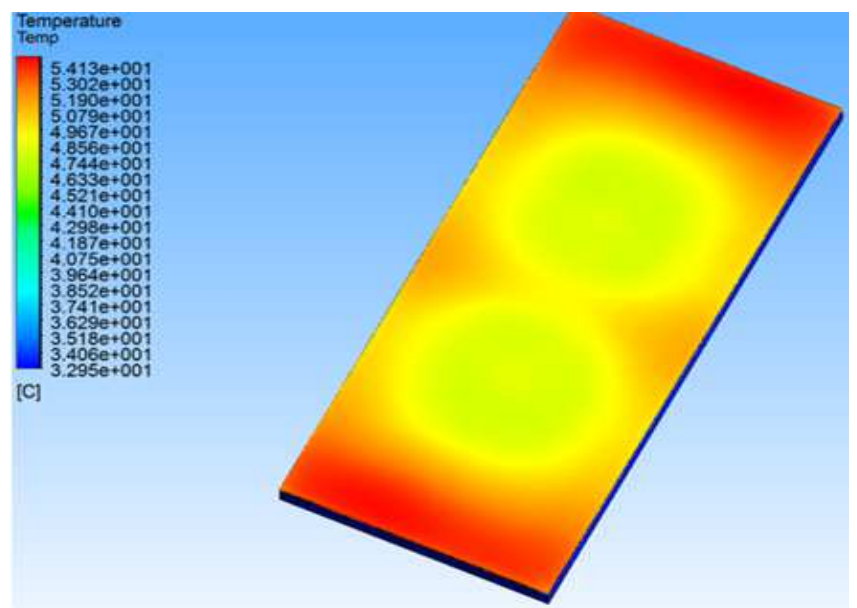

Fig. 5 Temperature distribution of PV panel with $2 \mathrm{~m} / \mathrm{s}$ of DC fan flow rate 


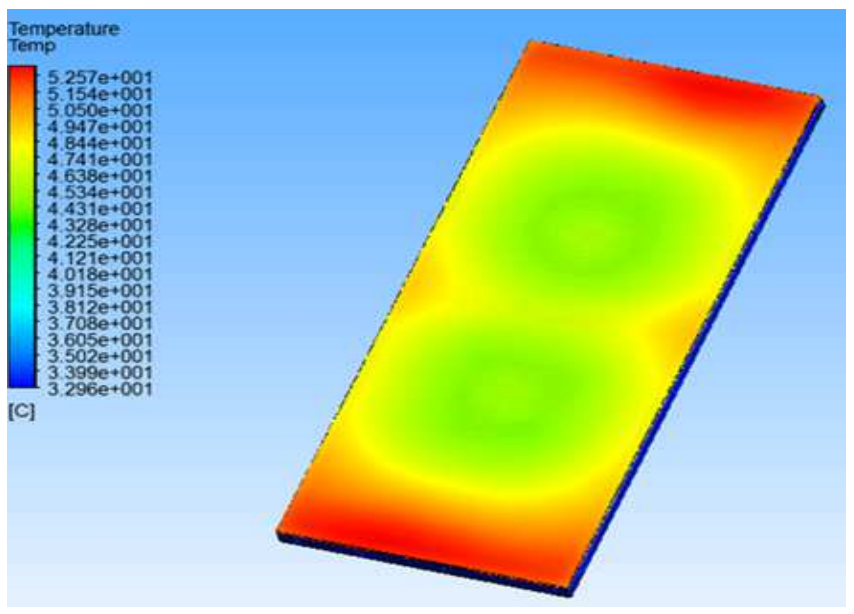

Fig. 6 Temperature distribution of PV panel with $4 \mathrm{~m} / \mathrm{s}$ of DC fan flow rate

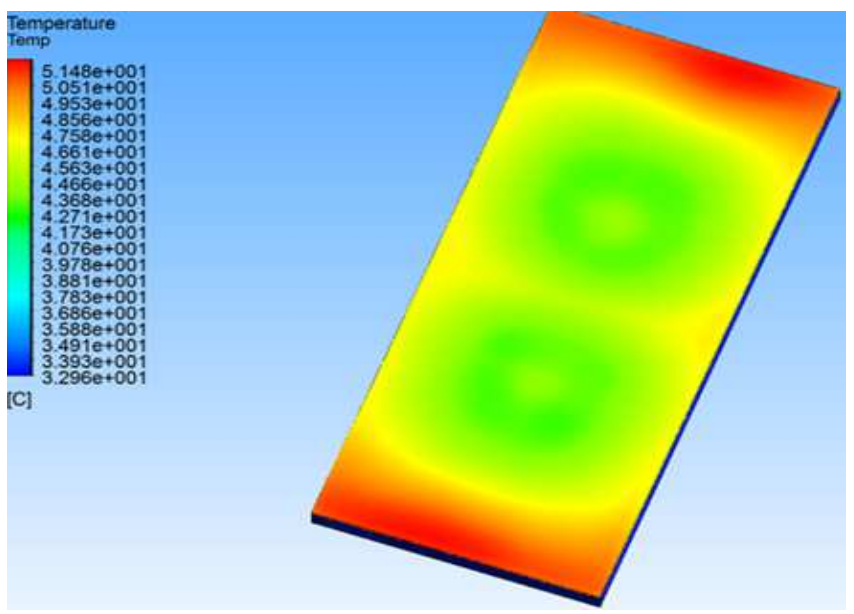

Fig. 7 Temperature distribution of PV panel with $6 \mathrm{~m} / \mathrm{s}$ of DC fan flow rate

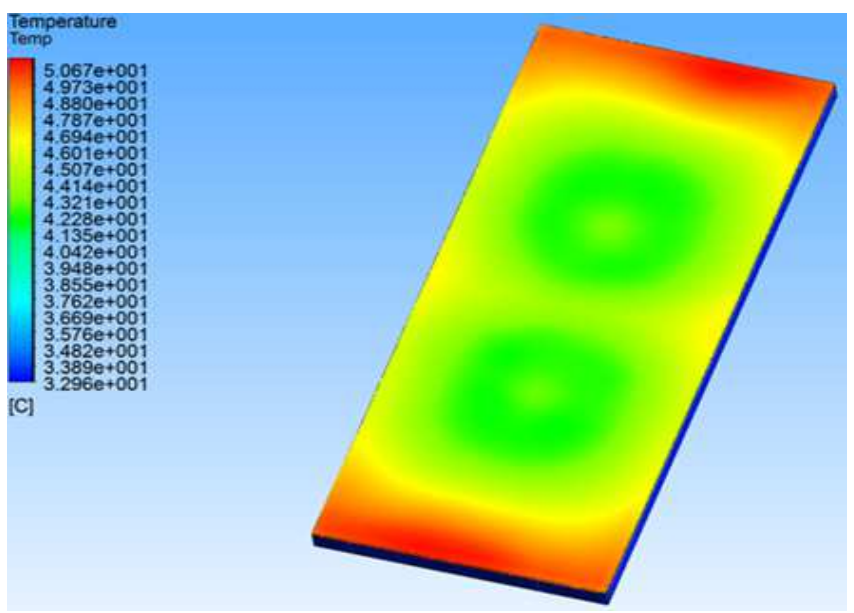

Fig. 8 Temperature distribution of PV panel with $8 \mathrm{~m} / \mathrm{s}$ of DC fan flow rate

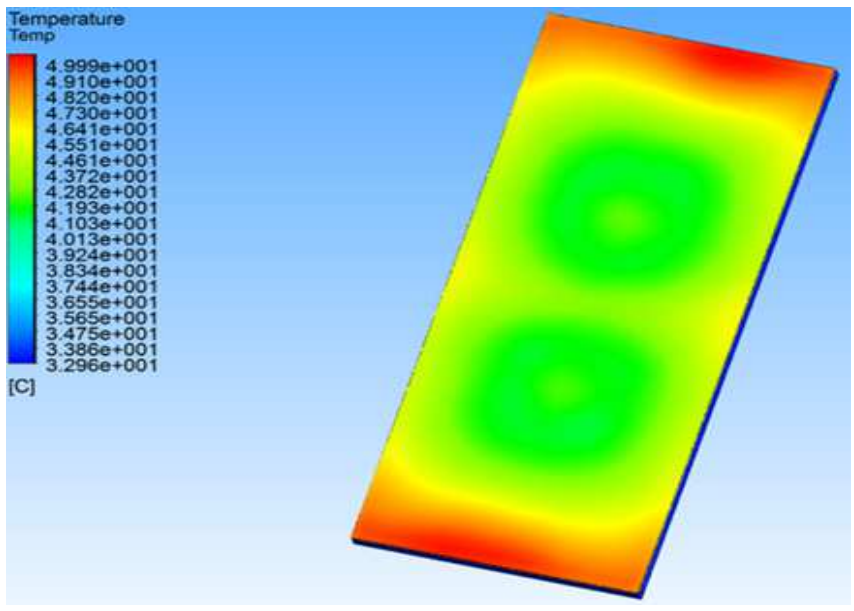

Fig. 9 Temperature distribution of PV panel with $10 \mathrm{~m} / \mathrm{s}$ of DC fan flow rate

Fig. 4 displays the temperature distribution on the PV panel without cooling system. While, Fig 5-9 shows the temperature distribution on the PV panel with a cooling system for the effect of DC fan flow rate. The selected range of DC fan flow rate was taken from $2 \mathrm{~m} / \mathrm{s}$ to $10 \mathrm{~m} / \mathrm{s}$. From these figures above, each of the PV panels consists of a contour plot of temperature distribution. Various colour of a contour plot is represented different values of temperature. The bright-red colour is represented the hottest area of the geometry model that consists of the highest temperature. On the other hand, the dark-blue colour is a sign of the coldest area of the geometry model. This represent the lowest temperature that produced by the PV panel.

It can be observed that the surface of the PV panel without cooling system is majority covered by the bright red colour. Which means that PV panel was generated more heat energy. This is because the natural convection just employed to transfer heat energy from the PV panel to the surrounding. Therefore, it can dissipate less heat energy to surrounding. On the contrary, the PV panel with cooling system was applied natural convection and forced convection to exhaust the heat energy from the PV panel to surrounding. As a result, it leads to the PV panel generated low temperature. It can find out that the surface of PV panel with the cooling system was appeared two large circles. This is because the DC fans are blowing fresh air into the air channel to provide the cooling effect for the PV panel. It can be discovered that the surface of the cold circle is the smallest and majority surface of the PV panel is covered by orange colour at $2 \mathrm{~m} / \mathrm{s}$ of DC fan flow rate than other DC fan flow rates. However, the surface of cold circle at the PV panels has been bigger as increased in flow rate of the DC fan. This can be seen that the surface of cold circle is the biggest at $10 \mathrm{~m} / \mathrm{s}$ of DC fan flow rate than other DC fan flow rates. Additionally, it can also be dissipated more heat energy from the PV panel lead to generate lower temperature. 


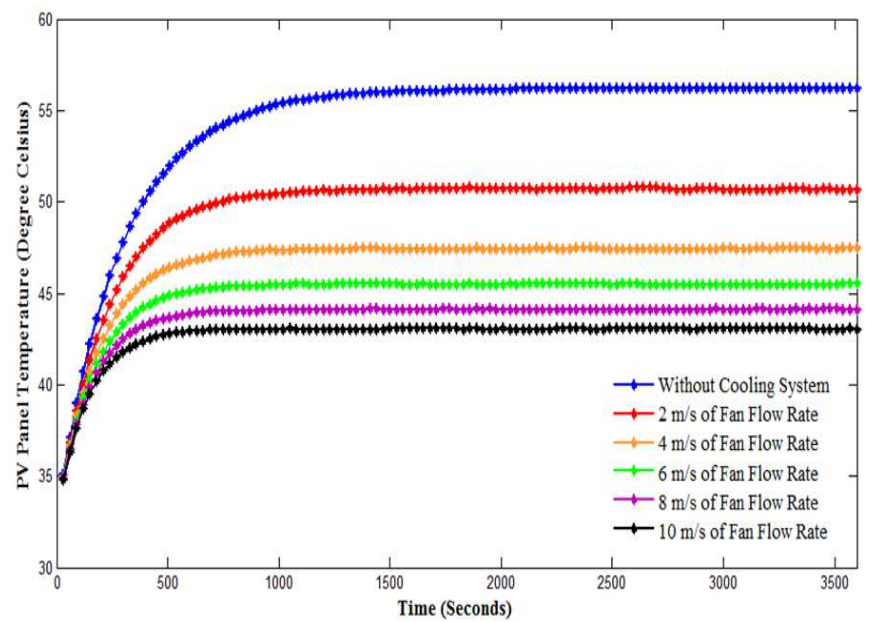

Fig. 10 Performance of PV panel with and without DC fan cooling system

Fig. 10 shows the effect of cooling system and effect of DC fan flow rate in the performance of PV panel. The selected range of DC fan flow rate was taken from $2 \mathrm{~m} / \mathrm{s}$ to $10 \mathrm{~m} / \mathrm{s}$. The average temperature for the PV panel without cooling system was $55^{\circ} \mathrm{C}$. While, the average temperature for the PV panel with cooling system decreased from $50{ }^{\circ} \mathrm{C}$ to $43{ }^{\circ} \mathrm{C}$ as the flow rate of DC fan increases from $2 \mathrm{~m} / \mathrm{s}$ to $10 \mathrm{~m} / \mathrm{s}$. When the flow rate of DC fan was applied at $2 \mathrm{~m} / \mathrm{s}$ and $4 \mathrm{~m} / \mathrm{s}$, the average temperature of the PV panel is $50{ }^{\circ} \mathrm{C}$ and $47{ }^{\circ} \mathrm{C}$, correspondingly. While, the flow rate of DC fan was applied at $6 \mathrm{~m} / \mathrm{s}, 8 \mathrm{~m} / \mathrm{s}$ and $10 \mathrm{~m} / \mathrm{s}$, the average temperature of the PV panel is $45^{\circ} \mathrm{C}, 44{ }^{\circ} \mathrm{C}$ and $43{ }^{\circ} \mathrm{C}$, respectively. It can be clearly that $\mathrm{PV}$ panel with cooling system can be generated lower temperature than without cooling system. In addition, the increment in flow rate of DC fan leads to decrease the temperature of PV panel. It can be proved that higher flow rate of DC fan applied for PV panel that it produces lower temperature performance.

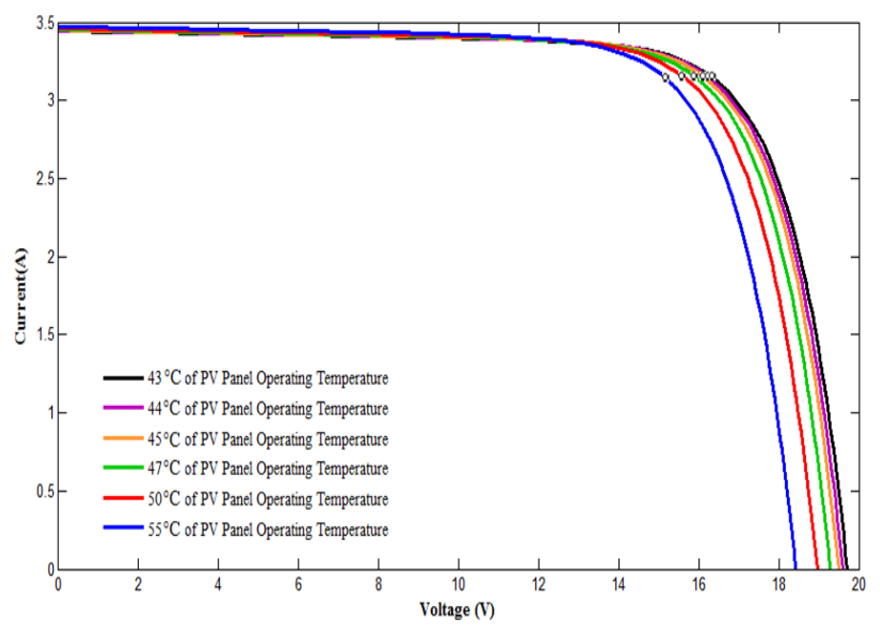

Fig. 11 Output power generated by PV panel with and without DC fan cooling system

Fig. 11 illustrates the output power of the PV panel with and without cooling system. The average solar irradiance and the average operating temperature of the PV panel were used to calculate the output power that generated by the PV panel. When the temperature of PV panel without cooling system is $55^{\circ} \mathrm{C}$, the PV panel can be generated $47.7 \mathrm{~W}$ as its output power. Whereas, for the PV panel with cooling system, PV panel can be generated $49.2 \mathrm{~W}, 50.2 \mathrm{~W}$ and 50.8 W of output power at the temperature of $50{ }^{\circ} \mathrm{C}, 47{ }^{\circ} \mathrm{C}$ and $45{ }^{\circ} \mathrm{C}$, correspondingly. Moreover, when temperature of PV panel is $44{ }^{\circ} \mathrm{C}$ and $43{ }^{\circ} \mathrm{C}$, it can be produced $51.1 \mathrm{~W}$ and $51.4 \mathrm{~W}$ of output power, respectively. It can be observed the PV panel with cooling system can be generated more output power than PV panel without the cooling system. This can be seen that a slight increase in output power from $49.2 \mathrm{~W}$ to $51.4 \mathrm{~W}$ as the temperature of PV panel decreased from $50{ }^{\circ} \mathrm{C}$ to $43{ }^{\circ} \mathrm{C}$ by increasing the flow rate of DC fan. Therefore, the higher flow rate of DC fan is recommended for better thermal behaviour and electrical behaviour of PV panel.

\section{CONCLUSIONS}

This research work is to predict the thermal behavior and electrical behavior of the PV panel by using a threedimensional geometry model. For given environmental and operating condition, the PV panel without cooling system was generated higher temperature than PV panel with the cooling system. This result lead to PV panel with the cooling system generated higher output power compare than PV panel without the cooling system. It was shown that PV panel with cooling system can be increased the output power from $49.2 \mathrm{~W}$ to $51.4 \mathrm{~W}$ in the $\mathrm{DC}$ fan flow rate range of $2 \mathrm{~m} / \mathrm{s}$ to $10 \mathrm{~m} / \mathrm{s}$ at a solar irradiance of $589.3 \mathrm{~W} / \mathrm{m}^{2}$ and ambient temperature of $32.97{ }^{\circ} \mathrm{C}$. It shows that higher flow rate of DC fan will assist to heat dissipation and enhancement in output power generated by PV panel.

\section{ACKNOWLEDGMENT}

The authors gratefully acknowledge to Kementerian Pengajian Tinggi Malaysia supported under Knowledge Transfer Program (KTP) and the contributions and cooperation from member Centre of Excellence for Renewable Energy (CERE), University Malaysia Perlis (UniMAP) for their work on the original version of this document.

\section{REFERENCES}

[1] H.G. Teo, P.S. Lee, and M.N.A. Hawlader, "An active cooling system for PV modules,” Applied Energy, vol. 90, pp. 309-315, 2012.

[2] M.A. Kibria, R. Saidur, F.A. Al-Sulaiman, and Md Maniruzzaman A. Aziz, "Development of a thermal model for a hybrid photovoltaic module and phase change materials storage integrated in buildings," Solar Energy, vol. 124, pp.114-123, 2016.

[3] Radziemska, E., "The effect of temperature on the power drop in crystalline silicon solar cells," Renewable Energy, vol. 28, pp. 1-12, 2013.

[4] Fahad Al-Amri, and Tapas Kumar Mallick, "Alleviating operating temperature of concentration solar cell by air active cooling and surface radiation," Applied Thermal Engineering, vol. 59, pp. 348354, 2013.

[5] A. D. Dhassa, E. Natarajan, and P. Lakshmi, "An investigation of temperature effects on solar photovoltaic cells and modules," IJE TRANSACTIONS B: Applications, vol. 27, pp.1713-1722, Nov. 2014.

[6] A.R. Amelia, Y.M. Irwan, M. Irwanto, W.Z. Leow, N. Gomesh, I. Safwati, and M.A.M. Anuar, "Cooling on photovoltaic panel using forced air convection induced by DC fan," International Journal of Electrical and Computer Engineering (IJECE), vol. 6, pp. 526-534, April. 2016.

[7] O. Zogou, and H. Stapountzis, "Experimental validation of an improved concept of building integrated photovoltaic panels," Renewable Energy, vol. 36, pp. 3488-3498, 2011. 
[8] F. Sarhaddi, S. Farahat, H. Ajam, A. Behzadmehr, and M. MahdaviAdeli, "An improved thermal and electrical model for a solar photovoltaic thermal (PV/T) air collector," Applied Energy, vol. 87, pp. 2328-2339, July. 2010.

[9] Jin-Hee Kim, Se-Hyeon Park, and Jun-Tae Kim. "Experimental performance of a photovoltaic-thermal air collector," Energy Procedia, vol. 48, pp. 888-894, 2014.

[10] Y.M. Irwan, W.Z. Leow, M. Irwanto, Fareq. M, A.R. Amelia, N. Gomesh, and I. Safwati, "Analysis air cooling mechanism for photovoltaic panel by solar simulator," International Journal of
Electrical and Computer Engineering (IJECE), vol. 5, pp.636-643, 2015.

[11] A.S. Kaiser, B. Zamora, R. Mazón, J.R. García, and F. Vera, "Experimental study of cooling BIPV modules by forced convection in the air channel," Applied Energy, vol. 135, pp. 88-97, 2014

[12] NiccolòAste, Giancarlo Chiesa, and Francesco Verri,"Design, development and performance monitoring of a photovoltaic-thermal (PVT) air collector," Renewable Energy, vol. 33, pp. 914-927,May. 2008 